\title{
Plant-Produced Basic Fibroblast Growth Factor (bFGF) Promotes Cell Proliferation and Collagen Production
}

\section{(ㄷ) (i) (우)}

\author{
Authors \\ Kaewta Rattanapisit 1, 5, Angkana Jantimaporn², Pornjira Kaewpungsup ${ }^{3}$, Balamurugan Shanmugaraj ${ }^{1,5}$, \\ Prasit Pavasant $^{3,4}$, Katawut Namdee ${ }^{2}$, Waranyoo Phoolcharoen ${ }^{1,5}$
}

\section{Affiliations}

1 Research Unit for Plant-Produced Pharmaceuticals, Chulalongkorn University, Bangkok, Thailand

2 National Nanotechnology Center (NANOTEC), National Science and Technology Development Agency (NSTDA), Pathum Thani, Thailand

3 Research Unit of Mineralized Tissue, Faculty of Dentistry, Chulalongkorn University, Bangkok, Thailand

4 Department of Anatomy, Faculty of Dentistry, Chulalongkorn University, Bangkok, Thailand

5 Department of Pharmacognosy and Pharmaceutical Botany, Faculty of Pharmaceutical Sciences, Chulalongkorn University, Bangkok, Thailand

Key word

cell proliferation, collagen, Fibroblast Growth Factor, Nicotiana benthamiana, Plant-produced recombinant protein, Solanaceae, Transient expression

$\begin{array}{ll}\text { received } & 09.07 .2020 \\ \text { revised } & 08.09 .2020 \\ \text { accepted } & 10.10 .2020\end{array}$

\section{Bibliography}

Planta Med Int Open 2020; 7: e150-e157

DOI 10.1055/a-1289-1265

ISSN 2509-9264

\section{(c) 2020. The Author(s).}

This is an open access article published by Thieme under the terms of the Creative Commons Attribution-NonDerivative-NonCommercial-License, permitting copying and reproduction so long as the original work is given appropriate credit. Contents may not be used for commecial purposes, or adapted, remixed, transformed or built upon. (https://creativecommons.org/ licenses/by-nc-nd/4.0/)

Georg Thieme Verlag KG, Rüdigerstraße 14,

70469 Stuttgart, Germany

\section{Correspondence}

Waranyoo Phoolcharoen

Department of Pharmacognosy and Pharmaceutical Botany Faculty of Pharmaceutical Sciences Chulalongkorn University 254 Phyathai Road Patumwa, Bangkok, 10330

Thailand

Tel.: +66 22188359 , Fax: +6622188357

Waranyoo.P@chula.ac.th
Katawut Namdee

National Nanotechnology Center (NANOTEC), National

Science and Technology Development Agency (NSTDA)

111 Thailand Science Park

Phahonyothin Rd. Khlong Luang

Pathumthani 12120

Thailand

Tel.: + 6625647100 , Fax: + 6625646985

katawut@nanotec.or.th

\section{ABSTRACT}

Human fibroblast growth factor regulates a broad spectrum of biological functions, including cell proliferation and tissue differentiation, and has a wider application in tissue engineering. Here, we described the production of human basic fibroblast growth factor in plants by using a geminiviral vector system. In this study, we transiently expressed basic fibroblast growth factor containing a $\mathrm{C}$-terminus $8 \mathrm{X}$-Histidine with and without a barley alpha amylase signal peptide in Nicotiana benthamiana. The expression level of basic fibroblast growth factor without the signal peptide was found to be higher than the basic fibroblast growth factor with the signal peptide. Further, the recombinant basic fibroblast growth factor was purified from the plant crude extract by two-step purification viz., ammonium sulfate precipitation and $\mathrm{Ni}$-affinity chromatography. Our results demonstrated that the purified plant-produced basic fibroblast growth factor was biologically active and promotes the proliferation of human periodontal ligament stem cells and human follicle dermal papilla cells in vitro. Moreover, the plantproduced basic fibroblast growth factor also induced collagen production in human dermal fibroblast cells. Our results suggest the potential use of plant-produced basic fibroblast growth factor as an antiaging and hair growth-promoting agent in the cosmetic industry. 


\section{Introduction}

The mechanical, protective, and restorative properties of skin decline with aging [1]. Extrinsic factors, such as ultraviolet rays, may cause tissue damage as implicated from antioxidant depletion with increased production of reactive oxygen species [2]. Recently, growth factors have been used in tissue engineering due to their major role in skin rejuvenation. Growth factors regulate cell growth, proliferation, and differentiation via signaling pathways [3,4]. Growth factors such as epidermal growth factor [5,6], vascular endothelial growth factor [7], and acidic fibroblast growth factor [8] are used in cosmetic products intended for skin rejuvenation. Among the several human growth factors, basic fibroblast growth factor (bFGF) is one of the most wellknown ingredients in the cosmetic industry. bFGF is one of the members of the FGF family that has significant roles in cell proliferation, migration, differentiation, and survival, which are often implied applied to wound healing and tissue repair functions $[9,10]$. Five isoforms of human bFGF exist with a molecular mass (18, 22, 22.5, 24, and $34 \mathrm{kDa}$ ). The lower molecular weight isoform $18 \mathrm{kDa}$ is considered the main prototype of the FGF family [10]. In clinical interpretations, bFGF treatment can enhance the quality of burned skin, reduce hardness, and promote wound healing.

The recent advancement of cloning techniques has revolutionized molecular biology towards expressing commercially viable recombinant proteins in heterologous expression systems [11]. Recombinant bFGF is produced in a wide range of cell-based platforms, including bacteria [12,13], yeast [14], insects [15], and plants [16, 17]. More recently, the plant expression system has gained increasing interest for the production of various recombinant and therapeutic proteins. Studies showed that plant-produced proteins show functional activity and efficacy both in vitro and in vivo [18-23]. Plant-based transient expression is one of the effective methods for recombinant protein production in a short time. It offers unique advantages over other conventional systems, especially cost-effective processing costs, production speed, scale-up capability, post-translational modification, and free from human pathogen contamination [24].
Plant-produced proteins can be purified by multiple techniques, such as precipitation, ion-exchange chromatography, and affinity chromatography. In particular, affinity chromatography is extensively used. It can purify proteins based on the interaction of ligands with a specific protein, for example, polyhistidine, HA-tagged, Fc domain of immunoglobulin, etc. The polyhistidine tag, which can vary from 6 to 10 histidine residues, is the most common protein tagging sequence utilized for chromatographic purification $[8,22,25,26]$.

In this study, we compare the expression of bFGF with and without the barley alpha amylase signal peptide in a plant-based expression system using transient expression. We utilized the geminiviral replicon system derived from the bean yellow dwarf virus $[27,28]$ for rapid production of human bFGF in N. benthamiana. The $8 \mathrm{X}$-Histidine tag was added to bFGF at the $\mathrm{C}$-terminus to facilitate purification by Ni-affinity chromatography. The plant-produced bFGF was further purified and characterized. Our results showed that the expression level of plant-produced bFGF without the barley alpha amylase signal peptide is higher than that of the plantproduced bFGF with a signal peptide. In addition, plant-produced bFGF can induce the proliferation of human periodontal ligament cells and human follicle dermal papilla cells, and also promote the collagen production in human dermal fibroblast cells.

\section{Results and Discussion}

Human bFGF was transiently expressed in tobacco plants. To evaluate the effect of the signal peptide on expression efficiency, the signal peptide from barley alpha amylase was utilized for the present study. For the protein purification, $8 \mathrm{X}$-Histidine tag was fused at the C-terminus. The bFGF was produced by transient expression in N. benthamiana leaves by using PBY-SP-bFGF and pBY-bFGF expression cassettes ( $>$ Fig. 1 ). Leaf necrosis was observed after 3 days post-infiltration for $\mathrm{PBY}$-SP-bFGF construct whereas necrosis was observed after 4 days for the pBY-bFGF construct ( $>$ Fig. 2 a).

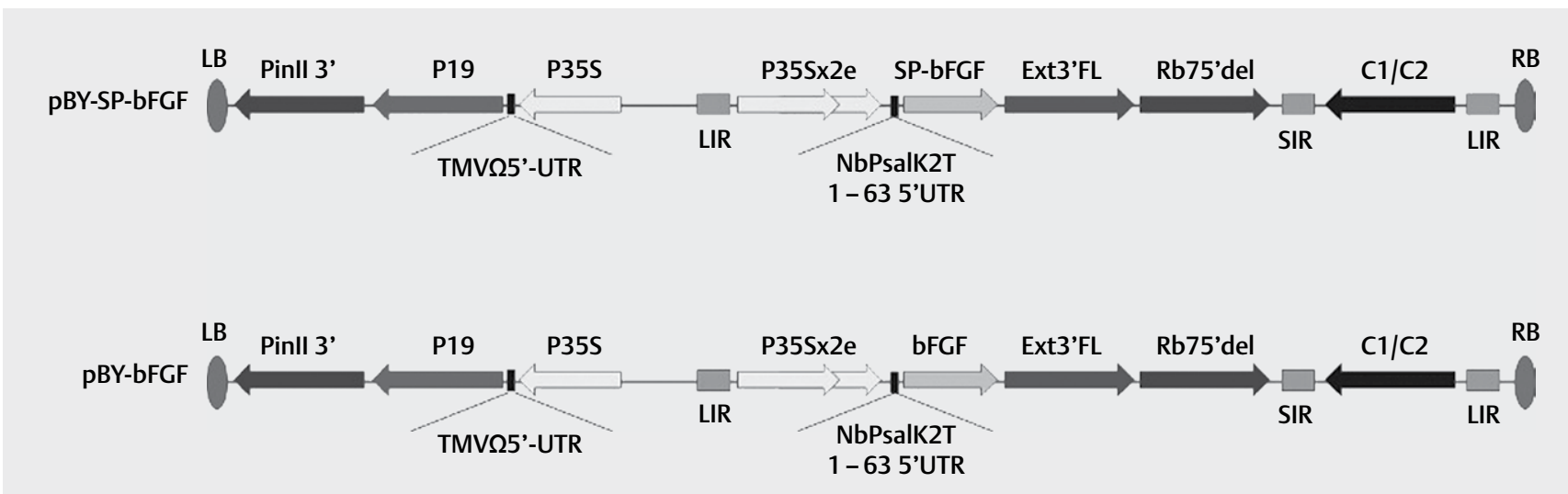

\footnotetext{
- Fig. 1 Schematic diagram of the geminiviral vector containing the hFGF gene. LB and RB: the left and right borders of the agrobacterium T-DNA region; P35S: cauliflower mosaic virus (CaMV) 35S promoter; TEV 5': tobacco etch virus 5' UTR; P19: P19 gene from the tomato bushy stunt virus (TBSV); Pin II 3': 3' of the proteinase inhibitor II gene; LIR: long intergenic region of the BeYDV genome; NbP 5': 5' of the nicotiana photosystem I reaction center subunit psaK; Ext3'FL: 3' of the nicotiana extension gene; Rb7 5': 5' of the Rb7 matrix attachment region/scaffold attachment region; SIR: short intergenic region of the BeYDV genome; C1: bean yellow dwarf virus (BeYDV) ORFs C1 and C2, which encode for the replication initiation protein (Rep) and RepA; SP-bFGF: human fibroblast growth factor gene with 8X-Histidine residues at C-terminus and signal peptide at N-terminus; bFGF: human fibroblast growth factor gene with $8 \mathrm{X}$-Histidine residues at C-terminus.
} 
The results showed that both constructs have a similar protein expression level on day 2 after agroinfiltration ( $\mathbf{F i g}$. 2b). For pBYbFGF, the protein expression level was significantly increased on day 3 and day 4 post-infiltration, accumulating protein levels up to 2.16 and $2.72 \mu \mathrm{g} / \mathrm{g}$ fresh weight, respectively ( $\mathbf{F i g}$. 2 b). The ex-

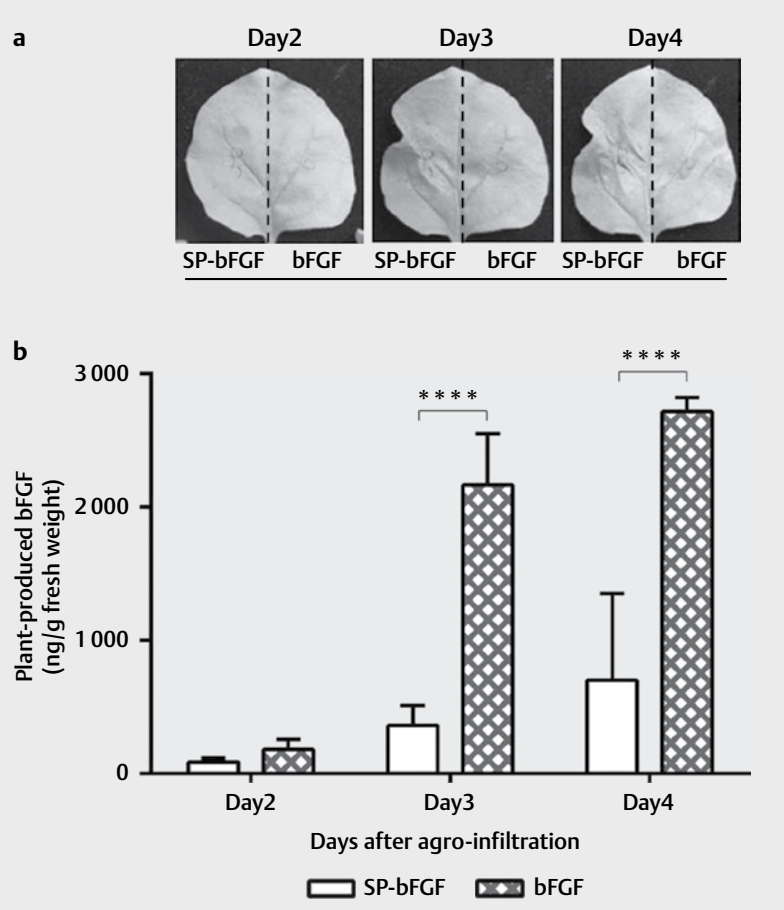

Fig. 2 Comparison of bFGF expression using PBY-SP-bFGF and pBY-bFGF vectors. Typical phenotype of $N$. benthamiana leaves expressing recombinant bFGF using PBY-SP-bFGF (left) and pBY-bFGF (right) on days 2, 3, and 4 after infiltration a. $N$. benthamiana leaves were harvested and $\mathrm{bFGF}$ protein expression was determined by ELISA b. Data represent means \pm SD, ${ }^{* * * *} p<0.0001$. pression level of bFGF produced from transient expression in the plant was lower compared to other expression systems [12-16]. This phenomenon might be due to the rapid necrosis exhibited by infiltrated leaves. Relatively, tissue necrosis is postulated to affect protein expression and stability [29, 30]. In comparison between the two constructs, the expression level of bFGF from the pBY-bFGF cassette was approximately 5-fold higher than the pBY-SP-bFGF construct. The difference in the expression level of bFGF with and without the signal peptide varied depending on the stability of the protein in different locations. Based on the results, the pBY-bFGF gene construct was used for further experiments to produce bFGF.

To establish a simple and efficient purification protocol for plantproduced bFGF, two-step purification by ammonium sulfate precipitation and Ni-affinity chromatography were carried out. Onestep purification with $\mathrm{Ni}$-affinity chromatography showed that the purified protein contained some of the plant proteins, especially rubisco, which is the most abundant protein in plants ( $\bullet$ Fig. $\mathbf{3 a}$ ). However, preceding purification by ammonium sulfate precipitation, specifically after the addition of $35 \%$ ammonium sulfate salt, showed the removal of more than $50 \%$ of rubisco ( $>$ Fig. $\mathbf{3 b}$ ). Previous studies have also shown that $35 \%$ ammonium sulfate precipitation can effectively remove most of the rubisco protein [31]. The bFGF was precipitated at $80 \%$ ammonium sulfate and subsequently purified by Ni-affinity column chromatography ( $>$ Fig. $\mathbf{3 b}$ ). With this two-step purification, the purity of the plant-produced bFGF was enhanced.

Human periodontal ligament stem cells (hPDLSCs) play a key role in tissue engineering. Previous studies demonstrated that bFGF is necessary for hPDLSCs proliferation [32]. To investigate the effect of plant-produced bFGF protein in the proliferation of hPDLS$\mathrm{Cs}$, the cells obtained from three different donors were treated with $2 \mathrm{ng} / \mathrm{mL}$ of plant-produced bFGF and $20 \mathrm{ng} / \mathrm{mL}$ of $E$. coli-produced bFGF for 3 days prior to the cell viability measurement. Our results showed that plant-produced bFGF significantly induced the proliferation of hPDLSCs compared to untreated cells ( $>$ Fig. 4). Both plant-produced and $E$. coli-produced bFGF can activate the prolif-

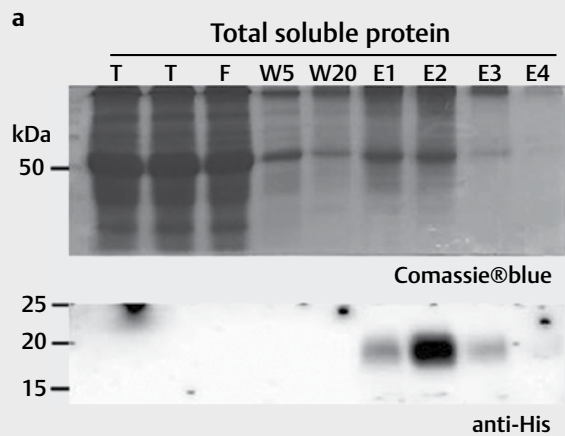

b
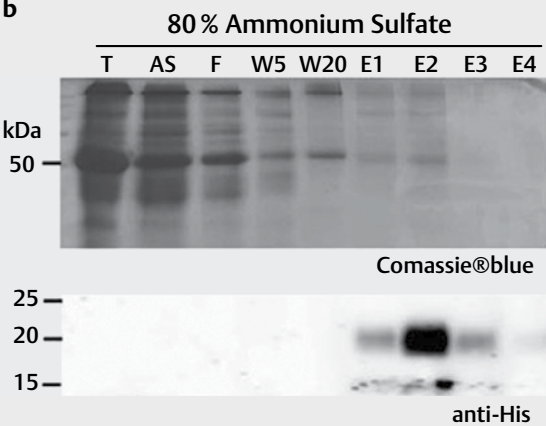

- Fig. 3 Purification of bFGF from the plant crude extract by ammonium sulfate precipitation. Total soluble protein a or plant protein precipitated at $35-80 \%$ ammonium sulfate saturation b. Plant-produced bFGF was purified using Ni-NTA affinity chromatography. The purified protein was separated by SDS-PAGE and stained with Coomassie blue stain; Western blot with anti-histidine antibody conjugated with HRP. T: total soluble protein from the plant crude extract; AS: plant proteins precipitated at 35-80\% ammonium sulfate saturation; F: flow though; Wash 5 (W5): fraction collected during washing with buffer containing $5 \mathrm{mM}$ imidazole; Wash 20 (W20): fraction collected during washing with buffer containing $20 \mathrm{mM}$ imidazole; E1: elution fraction 1; E2: elution fraction 2; E3: elution fraction 3; E4: elution fraction 4. 
eration of hPDLSCs, but the dose of plant-produced bFGF was 10 times lower ( $\triangleright$ Fig. 4). Our results confirmed that the plant-produced bFGF can be used for the maintenance of stemness in hPDLSCs.

A previous study showed that FGFs, including bFGF, can promote hair growth in mice [33]. Dermal papilla cells are one of the regulators of the hair cycle [34]. To investigate the effect of recombinant bFGF in the proliferation of human follicle dermal papilla cells (hFDPCs), the cells were treated with 50,100 , and $200 \mathrm{ng} / \mathrm{mL}$ of plant-produced bFGF or E. coli-produced bFGF for $24 \mathrm{~h}$. Our results showed that both plant-produced and $E$. coli-produced bFGF significantly induced the proliferation of hFDPCs compared to untreat-

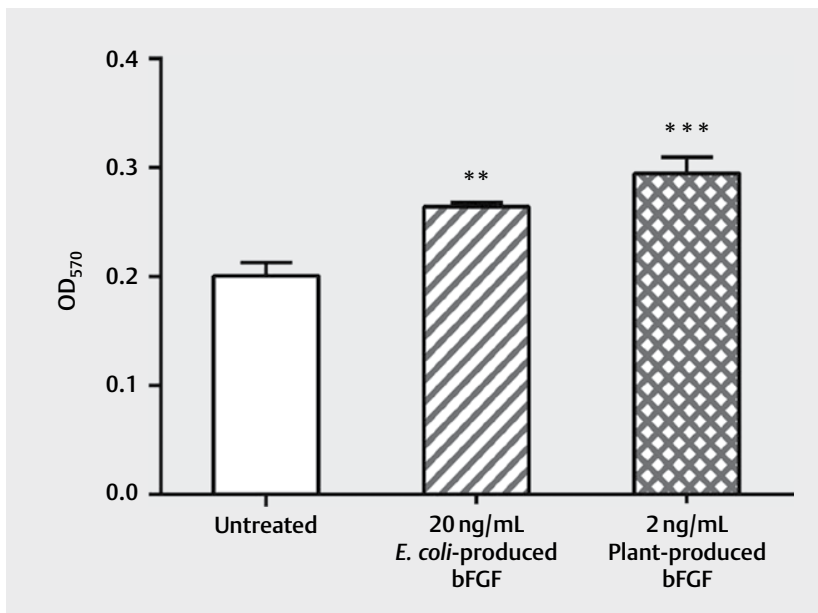

- Fig. 4 The effect of plant-produced bFGF on human periodontal ligament stem cell (hPDLSC) proliferation evaluated by the MTT assay. Cells were treated with $2 \mathrm{ng} / \mathrm{mL}$ of plant-produced bFGF, and $20 \mathrm{ng} / \mathrm{mL}$ of $E$. coli produced bFGF for 3 days prior to cell viability measurement. Data represent means $\pm S D ;{ }^{* *} p<0.01$ and ${ }^{* * *} \mathrm{p}<0.001$. ed cells ( $\triangleright$ Fig. 5), suggesting that plant-produced bFGF might be a good candidate for activating the hair cycle and hair growth.

Reduction of collagen stimulates the manifestation of wrinkles in skin [35]. Therefore, the induction of collagen production is essential for antiaging products. bFGF has a role on collagen-related gene expression [35-37]. To investigate collagen induction in primary dermal fibroblast cells (hDFBCs), the cells were treated with $25 \mathrm{ng} / \mathrm{mL}$ of plant-produced bFGF and vitamin C (VitC, control) for 6 days. The results showed that both plant-produced FGF and vitamin C induce cell proliferation compared to untreated cells ( $\triangleright$ Fig. $\mathbf{6 a}$ ). The collagen in the cells was stained with direct red 80 in picric acid. Our results showed that the hDFBCs treated with plant-produced bFGF produced more collagen than the untreated cells. The percentage of total stained collagen confirmed that the plant-produced bFGF significantly induced collagen production in hDFBCs ( $\vee$ Fig. 6b, c). This result suggests that plant-produced bFGF might be an effective ingredient in antiaging skin care, supposing its induction capacity for collagen production in hDFBCs.

Overall, the present study demonstrates that recombinant bFGF produced transiently in $N$. benthamiana leaves promotes the proliferation in hPDLSCs and hFDPCs, even in a minimal concentration, compared with $E$. coli-produced bFGF. Interestingly, it also stimulates collagen production in hDFBCs. Our results strongly support the promising potential of plant-produced bFGF as an antiaging and anti-hair loss agent in the cosmetic industry.

\section{Materials and Methods}

\section{Vector construction}

The nucleotide sequence of bFGF (Genbank Accession No: AAQ73204.1) linked with 8X-Histidine at C-terminus was plant codon optimized and synthesized by GeneArt gene synthesis (Thermo Scientific). The gene was cloned in two constructs either with or without barley alpha amylase signal peptide at N-terminus, SPbFGF, and bFGF, respectively. The genes were cloned in a geminiviral

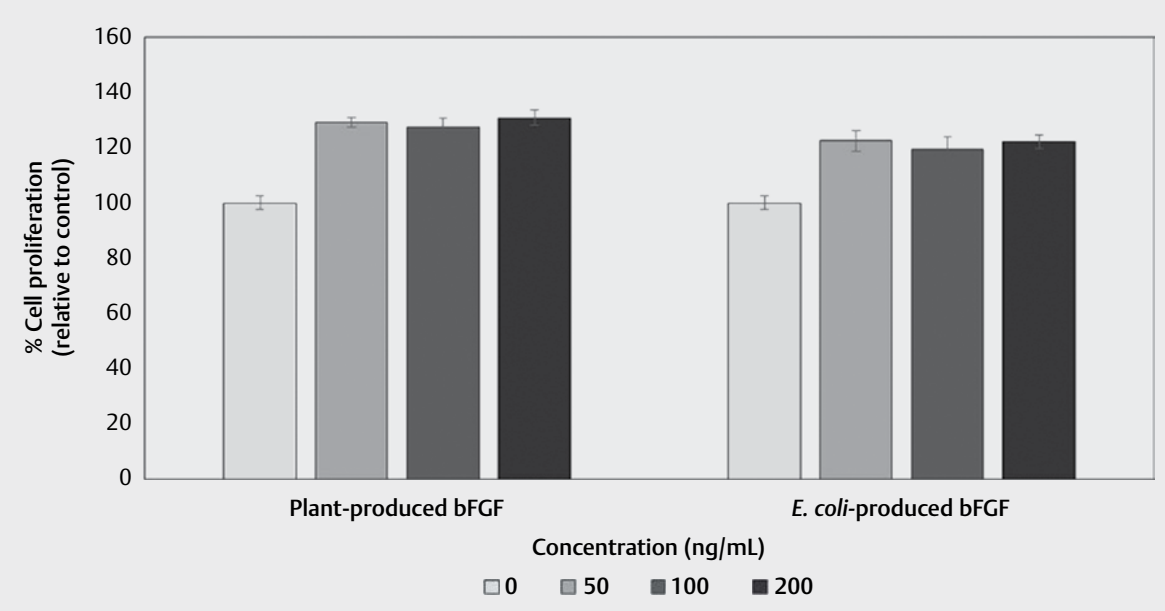

- Fig. 5 The effect of plant-produced bFGF on human follicle dermal papilla cell (hFDPCs) proliferation was evaluated by the Cell Titer-Glo ATP assay. The cells were treated with 50,100 , and $200 \mathrm{ng} / \mathrm{mL}$ of plant-produced bFGF and $E$. coli-produced bFGF for $24 \mathrm{~h}$. Cell proliferation was tested by using Cell Titer-Glo reagent. Data represent means \pm SD; ${ }^{* *} p<0.05$. 
a

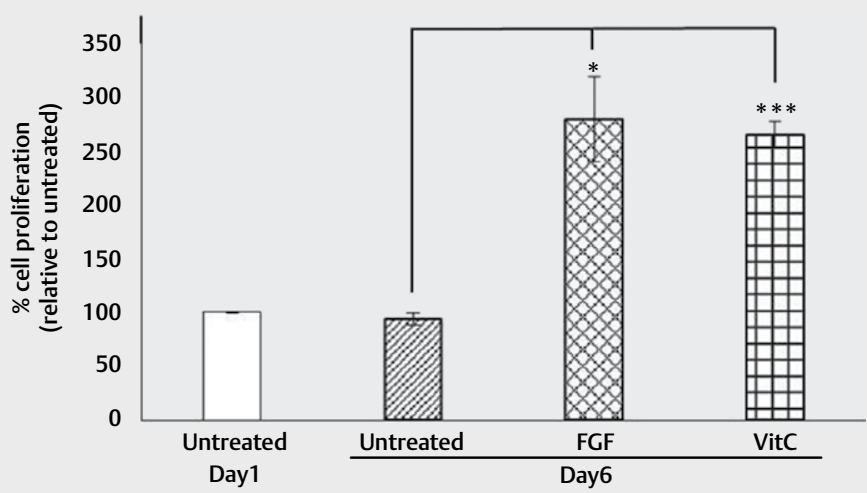

b
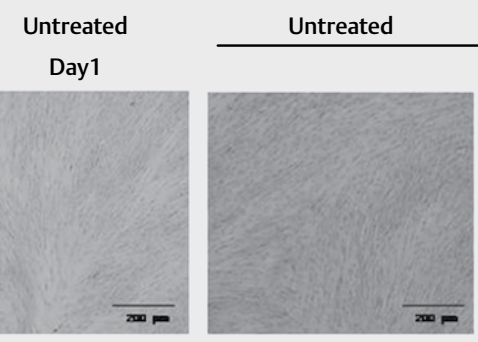

Plant-produced bFGF VitC
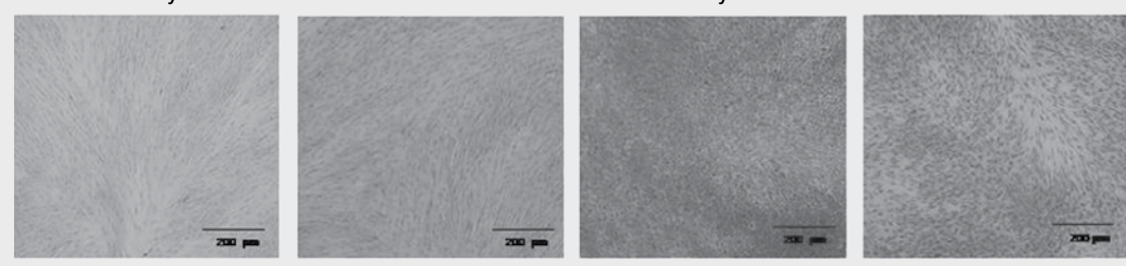

c

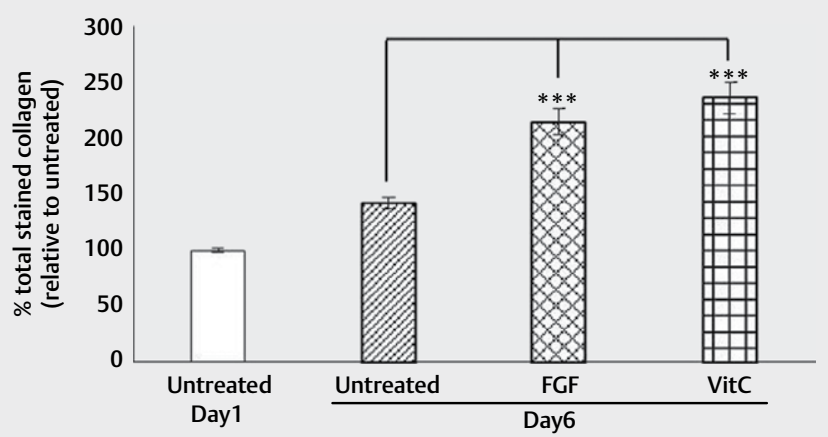

- Fig. 6 The effect of plant-produced bFGF on collagen production in human dermal fibroblast cells (hDFBCs). Cells were treated with $25 \mu \mathrm{g} / \mathrm{mL}$ of plant-produced FGF and VitC for 6 days. Cell proliferation a, picrosirius red staining images of human dermal fibroblasts showing collagen $\mathbf{b}$, and total collagen production $c$. Data represent means \pm SEM; ${ }^{*} p<0.05$ and ${ }^{* * *} p<0.005$.

vector (pBY2eK2Md) with Xbal and Sacl restriction sites (• Fig. 1). Agrobacterium tumefaciens strain GV3101 was transformed with plasmid pBY-SP-bFGF and pBY-bFGF for transient expression in N. benthamiana.

\section{Recombinant protein production in Nicotiana benthamiana}

To compare the expression level of both constructs, $A$. tumefaciens cells containing either $\mathrm{pBY}$-SP-bFGF or pBY-bFGF were infiltrated with OD600 0.2 in N. benthamiana leaves. The infiltrated leaves were harvested on days 2,3 , and 4 post-infiltration. The leaves were gound, extracted with extraction buffer $(5 \mathrm{mM}$ imidazole, $20 \mathrm{mM}$ Tris- $\mathrm{HCl}$ $\mathrm{pH} 7.4,50 \mathrm{mM} \mathrm{NaCl}$ ), and centrifuged at $26000 \mathrm{~g}$ at $4^{\circ} \mathrm{C}$ for $15 \mathrm{~min}$. The supernatant was quantified for the amount of bFGF using the human FGF basic ELISA Kit (R\&D System). Experiments were conducted in triplicate and all the data are presented as the mean \pm SD.

\section{Purification of plant-produced basic fibroblast growth factor}

For large scale protein expression, the Agrobacterium strain harboring bFGF (OD600 0.2) was vacuum infiltrated into 6- to 8-week old $N$. benthamiana plants. Infiltrated plants were kept under a 16-h light/8-h dark cycle at $28^{\circ} \mathrm{C}$ for 3 days. Next, the leaves were harvested (400 g) and homogenized using a blender with the extraction buffer. The crude extract was centrifuged at $26000 \mathrm{~g}$ at $4{ }^{\circ} \mathrm{C}$ for $45 \mathrm{~min}$. The supernatant was purified by ammonium sulfate precipitation and $\mathrm{Ni}$-affinity chromatography. For ammonium sulfate precipitation, ammonium sulfate salt was initially added into the supernatant until $35 \%$ saturation and centrifuged at $26000 \mathrm{~g}$ at $4{ }^{\circ} \mathrm{C}$ for $10 \mathrm{~min}$. Then, ammonium sulfate salt was further added into the $35 \%$ saturated supernatant until $80 \%$ saturation and centrifuged at $26000 \mathrm{~g}$ at $4{ }^{\circ} \mathrm{C}$ for $10 \mathrm{~min}$. The 35 and $80 \%$ resulting pellets were resuspended with extraction buffer for Ni-NTA column 
purification (35\% AS and $80 \%$ AS). All solutions were filtered with a $0.4-\mu \mathrm{m}$ filter and loaded into a Ni-affinity column. After washing with $10 \mathrm{CV}$ washing buffer 5 (Wash 5; $5 \mathrm{mM}$ imidazole, $20 \mathrm{mM}$ Tris$\mathrm{HCl} \mathrm{pH} \mathrm{7.4,} 50 \mathrm{mM} \mathrm{NaCl}$ ) and $10 \mathrm{CV}$ washing buffer 20 (Wash 20; $20 \mathrm{mM}$ imidazole, $20 \mathrm{mM}$ Tris- $\mathrm{HCl}$ pH 7.4, $50 \mathrm{mM} \mathrm{NaCl}$ ), the purified protein was eluted with elution buffer ( $250 \mathrm{mM}$ imidazole, $20 \mathrm{mM}$ Tris- $\mathrm{HCl}$ pH 7.4, $50 \mathrm{mM} \mathrm{NaCl}$ ) and analyzed by SDS-PAGE and Western blot probed with HRP-conjugated rabbit polyclonal anti-6x His tag antibody (Abcam). The concentration of plant-produced bFGF was determined by ELISA.

\section{SDS-PAGE and Western blot}

The protein samples were mixed with loading buffer [ $125 \mathrm{mM}$ Tris- $\mathrm{HCl}$ $\mathrm{pH} 6.8,12 \% \mathrm{SDS}, 10 \%$ (v/v) glycerol, $22 \%$ (v/v) $\beta$-mercaptoethanol, $0.001 \%(w / v)$ bromophenol blue] and denatured for $5 \mathrm{~min}$. The denatured protein was separated on $15 \%$ SDS-PAGE and stained with Coomassie brilliant blue R-250 (AppliChem). For Western blot analysis, separated proteins were transferred to a nitrocellulose membrane (Bio-Rad) and probed with HRP-conjugated rabbit polyclonal anti-6x His tag (Abcam). The membranes were developed by chemiluminescence using ECL plus detection reagent (GE Healthcare).

\section{Culturing of human periodontal ligament stem cells and cell proliferation assay}

hPDLSCs were isolated according to a previous study [38]. The protocol was approved by the Ethical Committee (Study code: HRECDCU 2018-054; May 31, 2018), Faculty of Dentistry, Chulalongkorn University and informed consent was obtained from each donor. The hPDLSCs were removed from the middle one-third of the root. The explants were cultured in DMEM containing $10 \%$ FBS, 2 nM L-glutamine, 100 units $/ \mathrm{mL}$ of penicillin, $100 \mathrm{mg} / \mathrm{mL}$ of streptomycin, and $5 \mathrm{mg} / \mathrm{mL}$ of amphotericin B. Media and supplements were supplied by Gibco (Thermo Fisher Scientific). Cells were incubated at $37^{\circ} \mathrm{C}$ under $5 \% \mathrm{CO}_{2}$. Once the cell confluence was obtained, the cells were trypsinized with $0.25 \%$ trypsin-EDTA and subcultured in a ratio of $1: 3$ on $60 \mathrm{~mm}$ tissue culture dishes (Passage 1). The cells from three different donors were used for the experiments. For the hPDLSC proliferation experiment, the hPDLSCs were seeded at the density of $5 \times 104$ cell per well in a 24 -well plate and incubated for $24 \mathrm{~h}$. After incubation, cells were treated with either $2 \mathrm{ng} / \mathrm{mL}$ of plant-produced bFGF or $20 \mathrm{ng} / \mathrm{mL}$ of $E$. coli-produced bFGF (Cat. No.: 100-18B; Peprotech) as the positive control. Cells were harvested 3 days after treatment. Cell viability was determined by the MTT assay and detected by spectrophotometry at $570 \mathrm{~nm}$ using a reference wavelength of $630 \mathrm{~nm}$ on an ELX800UV universal microplate reader (Bio-Tek Instruments Inc.). The experiments were done in triplicate and all data are presented as the mean \pm SD.

\section{Culturing of human follicle dermal papilla cells and cell proliferation assay}

hFDPCs were procured from PromoCell (C-12071). Cells were cultured in follicle derma papilla cell growth medium (PromoCell) supplemented with $10 \% \mathrm{FBS}, 1 \%$ penicillin (100 units $/ \mathrm{mL}$ ) and $100 \mu \mathrm{g} /$ $\mathrm{mL}$ streptomycin, and $1 \%$ nonessential amino acid. Supplements were supplied from Gibco (Thermo Fisher Scientific). Cells were incubated at $37^{\circ} \mathrm{C}$ under $5 \% \mathrm{CO}_{2}$. For the hFDPCs study, the CellTi-
ter-Glo luminescent cell viability assay (Promega) was performed to evaluate the cellular ATP levels. Primary dermal fibroblasts were seeded at $2 \times 104$ cells/well into a 96-well plate and incubated for $24 \mathrm{~h}$. After incubation, cells were treated either with 50, 100, and $200 \mathrm{ng} / \mathrm{mL}$ of plant-produced bFGF or $E$. coli-produced bFGF (positive control) for $24 \mathrm{~h}$. Then, $1 \times$ cell culture lysis reagent (Promega) was added. After $10 \mathrm{~min}$, Cell Titer-Glo reagent was added and incubated at room temperature for $10 \mathrm{~min}$. Next, luminescence was measured using a microplate luminometer (SpectraMax L, Molecular Devices). The percentage of cell viability was calculated using the following equation:

Cell proliferation $(\%)=\frac{\text { Luminescence of treated cells } \times 100}{\text { Luminescence of untreated cells }}$

The experiments were performed in triplicate and all data are presented as the mean \pm SD.

\section{Determination of collagen content}

hDFBCs were procured from ATCC (PCS-201-010 TM). Cells were cultured in DMEM supplemented with $10 \% \mathrm{FBS}, 1 \%$ penicillin (100 units $/ \mathrm{mL}$ ) and $100 \mu \mathrm{g} / \mathrm{mL}$ of streptomycin, and $1 \%$ nonessential amino acid. Media and supplements were supplied from Gibco (Thermo Fisher Scientific). Cells were incubated at $37^{\circ} \mathrm{C}$ under $5 \%$ $\mathrm{CO}_{2}$ until reaching $90 \%$ of confluency. For collagen content determination, collagen content in the primary hDFBCs was investigated by the Picrosirius-polarization method [39]. Briefly, the cells were seeded and treated with $25 \mu \mathrm{g} / \mathrm{mL}$ of plant-produced FGF and vitamin C (VitC, Sigma; Cat. No.: A0278; control) for 6 days (media was replaced every 2 days). After treatment, cells were washed with $1 \times$ PBS 3 times and fixed with 4\% PFA for $10 \mathrm{~min}$. The cells were stained with $0.1 \%(\mathrm{~W} / \mathrm{V})$ direct red 80 in saturated picric acid for $10 \mathrm{~min}$. The excess dye was removed by $0.01 \mathrm{~N} \mathrm{HCl}$ in $70 \%$ ethanol. Stained collagen in cell culture was dissolved with $0.5 \mathrm{~N} \mathrm{NaOH}$ and absorbance was measured at $540 \mathrm{~nm}$ using a microplate reader (Synergy H1, BioTeK). The percentage of total stained collagen was calculated using the following equation:

Cell proliferation $(\%)=\frac{\text { Luminescence of treated cells } \times 100}{\text { Luminescence of untreated cells }}$

The experiments were performed in triplicate and all data are presented as the mean \pm SD.

\section{Funding}

This work was supported by Thailand Research Fund grant RSA628 0006. The authors would like to thank the Graduate School, Ratchadapisek Somphot Fund (KR) and The Second Century Fund (C2F), Chulalongkorn University (BS) for providing financial support.

\section{Acknowledgements}

We thank Associate Professor Hugh Mason (Arizona State University, United States) for providing geminiviral vectors. 


\section{Conflict of Interest}

The authors declare they have no conflict of interest.

\section{References}

[1] Anitua E, Pino A, Troya M. Biological stability of plasma rich in growth factors-derived autologous topical serum after three-months storage. J Drugs Dermatol 2018; 17: 1115-1121

[2] Oka S, Hirai ], Yasukawa T, Nakahara Y, Inoue YH. A correlation of reactive oxygen species accumulation by depletion of superoxide dismutases with age-dependent impairment in the nervous system and muscles of Drosophila adults. Biogerontology 2015; 16: 485-501

[3] Botchkarev VA, Sharov AA. BMP signaling in the control of skin development and hair follicle growth. Differentiation 2004; 72 : 512-526

[4] Ellman MB, Yan D, Ahmadinia K, Chen D, An HS, Im H]. Fibroblast growth factor control of cartilage homeostasis. J Cell Biochem 2013; 114: $735-742$

[5] Kim J, Jang JH, Lee JH, Choi JK, Park WR, Bae IH, Bae J, Park JW. Enhanced topical delivery of small hydrophilic or lipophilic active agents and epidermal growth factor by fractional radiofrequency microporation. Pharm Res 2012; 29: 2017-2029

[6] Kim H, Kong WH, Seong KY, Sung DK, Jeong H, Kim JK, Yang SY, Hahn SK. Hyaluronate-Epidermal Growth Factor Conjugate for Skin Wound Healing and Regeneration. Biomacromolecules 2016; 17: 3694-3705

[7] Luo D, Cao Y, Wu D, Xu Y, Chen B, Xue Z. Impact of intense pulse light irradiation on BALB/c mouse skin-in vivo study on collagens, matrix metalloproteinases and vascular endothelial growth factor. Lasers Med Sci 2009; 24: 101-108

[8] Ha JH, Kim HN, Moon KB, Jeon JH, Jung DH, Kim SJ, Mason HS, Shin SY, Kim HS, Park KM. Recombinant human acidic fibroblast growth factor (aFGF) expressed in Nicotiana benthamiana potentially inhibits skin photoaging. Planta Med 2017; 83: 862-869

[9] Akita S, Akino K, Imaizumi T, Hirano A. A basic fibroblast growth factor improved the quality of skin grafting in burn patients. Burns 2005; 31 : 855-858

[10] Zou H, Nie XH, Zhang Y, Hu M, Zhang YA. Effect of basic fibroblast growth factor on the proliferation, migration and phenotypic modulation of airway smooth muscle cells. Chin Med J (Engl) 2008; 121: 424-429

[11] Ashwini M, Balamurugan S, Balamurugan S, Sathishkumar R. Advances in molecular cloning. Mol Biol 2016; 50: 1-6

[12] Kwong KW, Ng KL, Lam CC, Wang YY, Wong WK. Authentic human basic fibroblast growth factor produced by secretion in Bacillus subtilis. Appl Microbiol Biotechnol 2013; 97: 6803-6811

[13] Soleyman MR, Khalili M, Khansarinejad B, Baazm M. High-level expression and purification of active human FGF-2 in Escherichia coli by codon and culture condition optimization. Iran Red Crescent Med J 2016; 18: e21615

[14] Mu X, Kong N, Chen W, Zhang T, Shen M, Yan W. High-level expression, purification, and characterization of recombinant human basic fibroblast growth factor in Pichia pastoris. Protein Expr Purif 2008; 59 282-288

[15] Wu X, Kamei K, Sato H, Sato SI, Takano R, Ichida M, Mori H, Hara S. High-level expression of human acidic fibroblast growth factor and basic fibroblast growth factor in silkworm (Bombyx mori L.) using recombinant baculovirus. Protein Exp Purif 2001; 21: 192-200

[16] An N, Ou J, Jiang D, Zhang L, Liu J, Fu K, Dai Y, Yang D. Expression of a functional recombinant human basic fibroblast growth factor from transgenic rice seeds. Int J Mol Sci 2013; 14: 3556-3567
[17] Ding SH, Huang LY, Wang YD, Sun HC, Xiang ZH. High-level expression of basic fibroblast growth factor in transgenic soybean seeds and characterization of its biological activity. Biotechnol Lett 2006; 28 : 869-875

[18] Zhang B, Shanmugaraj B, Daniell H. Expression and functional evaluation of biopharmaceuticals made in plant chloroplasts. Curr Opin Chem Biol 2017; 38: 17-23

[19] Fischer R, Stoger E, Schillberg S, Christou P, Twyman RM. Plant-based production of biopharmaceuticals. Curr Opin Plant Biol 2004; 7: $152-158$

[20] Phoolcharoen W, Bhoo SH, Lai H, Ma J, Arntzen C], Chen Q, Mason HS. Expression of an immunogenic Ebola immune complex in Nicotiana benthamiana. Plant Biotechnol ] 2011; 9: 807-816

[21] Cummings JF, Guerrero ML, Moon JE, Waterman P, Nielsen RK, Jefferson S, Gross FL, Hancock K, Katz JM, Yusibov V. Safety and immunogenicity of a plant-produced recombinant monomer hemagglutinin-based influenza vaccine derived from influenza $A$ (H1N1) pdm09 virus: A Phase 1 dose-escalation study in healthy adults. Vaccine 2014; 32: 2251-2259

[22] Rattanapisit K, Abdulheem S, Chaikeawkaew D, Kubera A, Mason HS, Ma JK, Pavasant P, Phoolcharoen W. Recombinant human osteopontin expressed in Nicotiana benthamiana stimulates osteogenesis related genes in human periodontal ligament cells. Sci Rep 2017; 7: 17358

[23] Young G, Mahlangu J, Kulkarni R, Nolan B, Liesner R, Pasi ], Barnes C, Neelakantan S, Gambino G, Cristiano LM, Pierce GF, Allen G. Recombinant factor VIII Fc fusion protein for the prevention and treatment of bleeding in children with severe hemophilia A. J Thromb Haemost 2015; 13: 967-977

[24] Shanmugaraj B, Bulaon C, Phoolcharoen W. Plant Molecular Farming: A Viable Platform for Recombinant Biopharmaceutical Production. Plants (Basel) 2020; 9: 842

[25] Bulaon CII, Shanmugaraj B, Oo Y, Rattanapisit K, Chuanasa T, Chaotham C, Phoolcharoen W. Rapid transient expression of functional human vascular endothelial growth factor in Nicotiana benthamiana and characterization of its biological activity. Biotechnol Rep 2020; 27: e00514

[26] Hanittinan O, Oo Y, Chaotham C, Rattanapisit K, Shanmugaraj B, Phoolcharoen W. Expression optimization, purification and in vitro characterization of human epidermal growth factor produced in Nicotiana benthamiana. Biotechnol Rep 2020; 28: e00524

[27] Chen Q, He J, Phoolcharoen W, Mason HS. Geminiviral vectors based on bean yellow dwarf virus for production of vaccine antigens and monoclonal antibodies in plants. Hum Vaccin 2011; 7: 331-338

[28] Diamos AG, Mason HS. Modifying the replication of geminiviral vectors reduces cell death and enhances expression of biopharmaceutical proteins in Nicotiana benthamiana leaves. Front Plant Sci 2018; 9: 1974

[29] Hamorsky KT, Kouokam JC, Jurkiewicz JM, Nelson B, Moore L], Husk AS, Kajiura H, Fujiyama K, Matoba N. N-glycosylation of cholera toxin B subunit in Nicotiana benthamiana: impacts on host stress response, production yield and vaccine potential. Sci Rep 2015; 5: 8003

[30] Rattanapisit K, Bhoo SH, Hahn TR, Mason HS, Phoolcharoen W. Rapid transient expression of cholera toxin B subunit (CTB) in Nicotiana benthamiana. In Vitro Cell Dev Biol Plant 2013; 49: 107-113

[31] Robinson SP, Streusand V], Chatfield JM, Portis AR. Purification and assay of rubisco activase from leaves. Plant Physiol 1988; 88: 1008-1014

[32] Li Y, Yu F, Liu Y, Liang Q, Huang Y, Xiang Q, Zhang Q, Su Z, Yang Y, Zhao Y. Sulfonated chitosan oligosaccharide alleviates the inhibitory effect of basic fibroblast growth factor on osteogenic differentiation of human periodontal ligament stem cells. J Periodontol 2020; 91: 975-985 
[33] Lin WH, Xiang LJ, Shi HX, Zhang J, Jiang LP, Cai PT, Lin ZL, Lin BB, Huang Y, Zhang HL, Fu XB, Guo DJ, Li XK, Wang XJ, Xiao J. Fibroblast growth factors stimulate hair growth through $\beta$-catenin and Shh expression in C57BL/6 mice. Biomed Res Int 2015; 2015: 730139

[34] Driskell RR, Clavel C, RendI M, Watt FM. Hair follicle dermal papilla cells at a glance. J Cell Sci 2011; 124: 1179-1182

[35] Zhang S, Duan E. Fighting against Skin Aging: The Way from Bench to Bedside. Cell Transplant 2018; 27: 729-738

[36] Ko MK, Kay EP. Regulatory role of FGF-2 on type I collagen expression during endothelial mesenchymal transformation. Invest Ophthalmol Vis Sci 2005; 46: 4495-4503
[37] Song R, Bian HN, Lai W, Chen HD, Zhao KS. Normal skin and hypertrophic scar fibroblasts differentially regulate collagen and fibronectin expression as well as mitochondrial membrane potential in response to basic fibroblast growth factor. Braz J Med Biol Res 2011; 44: $402-410$

[38] Pattamapun K, Tiranathanagul S, Yongchaitrakul T, Kuwatanasuchat J, Pavasant P. Activation of MMP-2 by Porphyromonas gingivalis in human periodontal ligament cells. J Periodontal Res 2003; 38 : 115-121

[39] Junqueira LCU, Bignolas G, Brentani RR. Picrosirius staining plus polarization microscopy, a specific method for collagen detection in tissue sections. Histochem J 1979; 11: 447-455 